\title{
Sciendo
}

\section{Aspects Determining the Auto-identification of Native Communities in Contemporary Peru}

\section{PAVLÍNA SPRINGEROVÁ - ZDEŇKA PICKOVÁ}

Department of Political Science

University of Hradec Králové, Hradec Králové, Czech Republic

pavlina.springerova@uhk.cz,pickovazdenka@gmail.com

\begin{abstract}
The case of Peru evinces quite specific aspects missing in other states with numerous indigenous minorities. During the second half of the 20th century, indigenous communities in local sierra were officially renamed as agrarian communities (comunidades campesinas), which resulted in wiping their identity away in exchange for land reform and incorporation to state structures. The status of native people has slightly improved since the introduction of a new constitution in 1993 and the implementation of responsive laws later. However, up to the present the self-identification with the terms Quechua, Aymara, indigenous, native, mestizo or campesino often results in extensive consequences stemming from the persisting racism and hierarchic society. This article deals with the impacts related to ethnicity and auto-identification in contemporary Peru, focusing on variables determining the status of indigenous people within the 25 Peruvian regions. The national census held in autumn 2017 incorporated for the first time in history the possibility of ethnic auto-identification. The anticipated results might outline a new direction in terms of social status and identification within the native communities.
\end{abstract}

KEY WORDS: Peru, Quechua, native communities, self-identification, racism, census 2017 


\section{Introduction}

The rights and status of indigenous people worldwide were given a priority in the last decades and became the key topic for the contemporary democracy. The native question has escalated since the 1990s when the United Nations Organization (UN) issued several conventions and resolutions supporting the rights of native people. In that period many states of Latin America incorporated a status of multiethnic and multicultural state into their constitutions (the vast majority for the first time) and acknowledged the rights of all indigenous inhabitants to use their native language, continue the cultural tradition, provide traditional education or apply the self-government in their lands, including the natural resources etc. The current Peruvian constitution which recognises a multicultural character of the state was released in 1993 and the Convention 169 by International Labour Organization (ILO) was ratified one year later. This convention was ratified by most of the states with numerous native populations. Convention 169 guarantees indigenous people all rights and also prevents their discrimination (ILO 1980).

A geographical barrier of the Andes helped to form the history of Peru, as it divides the state into sierra (mountains), selva (jungle) and costa (coast). The indigenous people inhabiting all three parts formed independent communities with very different styles of life. The greater diversity of native groups can be found in the selva region where isolation and inaccessibility enabled the communities to continue the traditional way of living. Even the laws were slightly different in the area of the Amazon forest in comparison with the rest of the state. The crucial document incorporating semi-autonomy and basic rights was the Ley de Comunidades Nativas y de Desarollo Agrario de la Selva y de Ceja de Selva (Law of the Native Communities and Agricultural Support in the Amazon Region) No. 20653 released in 1974 (ROBLES MENDOZA 2002:18-19). Due to this law, native communities of selva never had any problems with recognition or confirmation of their status. The great cultural diversity includes 15 language families and 47 different languages within 1907 communities (AIDESEP 2017).

In contrast, ethnicity of the communities in sierra continues to be a topic of heated discussions not only among the scholars but more importantly among the participants themselves. In general, it is believed that approximately $10 \%$ of local people incline to the category blancos (white), nearly $50 \%$ identify themselves as mestizos, only $20 \%$ feel like indigenas (indigenous) or andinos (Andean) and the rest of the inhabitants consider themselves to be campesinos (peasants) (THORP - PAREDES 2011:36). The vast majority of Andean indigenous people live in the five regions (Apurimac, Ayacucho, Cusco, Huancavelica and Puno) that form together so-called Andean trapezoid. Although the 
proportion ranges from 64 to $77 \%$, only a few communities use the term indigenous or original (PAJUELO TEVES 2006:42). The main reason originated in 1969 with the Ley de la Reforma Agraria (Law of the Agrarian Reform) No. 17716 which was supposed to divide lands larger than 65 ha and redistribute them to the people who actually worked there. Indigenous communities themselves obtained only $8 \%$ since the majority came under the competence of organisations and agricultural cooperatives. The change was all-including, indigenous communities became comunidades campesinas (agrarian communities) and even on 24th June, the Día del Indio become the Día del Campesino ${ }^{1}$ (ZAPATA - ROJAS 2013:124). This suggests that the communities accepted a guarantee of ownership and social benefits in exchange for ethnic deprivation, as they converted into the working or agrarian class. The situation remained unchanged until the late 1990s under the strict government of president Fujimori. Only compromise instrumental in maintaining the native culture was an implementation of the Quechua language as an official one. Similarly, the Aymara and other original languages were made official in the area of their predomination (LOMNÉ 2014:76).

Ethnic identity in Peru was shifting and changing throughout the history and regions. Therefore, native people present themselves and are perceived by the society in various ways. Since this seems to be a common problem in many cultures, there is a need for a brief outline of terms used in Peru. As a result of a negative connotation connected to the post-colonial era, it is no longer possible to use the term indio (Indian) for the native people in Latin America as nobody uses it for auto-identification or indication. The term indigena (indigenous) is the most suitable one for academic papers and government needs, although not even this one is commonly used for self-determination. Among the most controversial ones belongs the term cholo which was supposed to distinguish a descendant of mixed parents who tends to prefer traditional culture to the imported one. Nevertheless, similarly to the term indio, this word also gained a negative connotation (LOMNÉ 2014:82).

In order to avoid a negative label, a great number of native inhabitants still prefer the socioeconomic designation campesino (peasant) which only suggests their affiliation to the agrarian sphere of a society. As mentioned above, this term has also deep historical roots. Another politically correct term used either by indigenous people who refuse to be connected with native culture or by non-native inhabitants is mestizo, which became popular thanks to its neutrality. After the change of a political discourse in the 1990s, some of the inhabitants gradually accepted the term indigenous or original communities, even though only for the

1 24th of June was the Day of the Indian until 1969, then it was changed to Day of the Agrarian.

DOI: 10.2478/eas-2018-0010 C University of SS. Cyril and Methodius in Trnava. All rights reserved. 
whole group, not as individuals. As indicated above, the term native communities is used in Peru mainly for the people living in the Amazon area. Apart from the auto-identification, Peruvian government also used the primordial characteristics, such as biological appearance, language or geographical location in order to complete the statistics (LOMNÉ 2014:82, 84). This changed in 2017 when all people obtained the possibility of auto-identification in the official national census. The most common and most sensible option for the inhabitants to identify themselves is their particular culture. The vast majority would use terms like Aymara, Quechua, Wari or Chopcca instead of indigenous or Shipibo, Asháninka or Boras in place of natives. There are also natives who just simply use the word people in their own language to distinguish themselves. This form is popular in the area of Cusco where several communities began to use the word runa for indigenous people.

The following pages deal with the Peruvian specifics, complications and challenges connected with all mentioned forms of auto-identification. The $21^{\text {st }}$ century seems to be favourable to indigenous communities in Peru, although there are still many obstacles that need to be overcome. What is more, unlike in bordering states, in Peru does not exist any national organisation or party which could unite and shield all the native people nationwide. In Ecuador, Bolivia and partly in Colombia indigenous people had to fight for their rights and lands which helped to establish national indigenous movements. In spite of numerous indigenous communities in Peru, the agrarian reform prevented the formation of a powerful organisation. In addition, the widespread 1990s ethno-populism never embraced within the Peruvian borders, since that was the era of Fujimori's dictatorship based on populistic and social aspects rather than the ethnicity (MADRID 2011:268). Also, the absence of a national ethnic party makes the participation in decision-making and governance even more difficult. Some of the elites managed to utilise regional organizations for the promotion of indigenous rights, needs and suggestions. Those initiatives inspired the founding of the Ministry of Culture (Ministerio de Cultura), enabled the official use of native languages, supported the Ley de la Consulta Previa (Law of the Prior Consultation), fought for the possibility of autoidentification or maintained the right to self-governance at their lands. The latest goal of the regional indigenous organisations emerges from the need to restore ethnic pride.

The survey was based also on the field research within the Peruvian indigenous communities living in the regions of Ayacucho, Huancavelica, Huancayo (sierra), together with Tingo 
María, Pucallpa and VRAEM ${ }^{2}$ (selva). Apart from that, additional information was provided by the officials of regional municipalities and local governments or by the Ministry of Culture referents. Many studies concerning the lack of indigenous movement in Peru were written either by Peruvian or foreign scholars. The article focuses particularly on the specifics that prevent original people from claiming the allegiance to specific ethnicity or to indigenous origin in general. This phenomenon is also closely related to the (non-)cooperation among the communities and with the municipalities. The additional aim is to point out the influence of the recently taken steps with regard to a perception of indigenous culture and ethnicity in general.

\section{Persisting Racism and Discrimination}

Neither in Peru nor in Latin America in general, there exist the laws for determination of the ethnic identity ${ }^{3}$. On the contrary, the ethnic affiliation is becoming even more variable and flexible (PINXTEN - VERSTRAETE - LONGMAN 2004:91). Two types of ethnic identity can be distinguished, the private one which brings no consequences at all, and the public one that becomes a part of a collective action, mobilisation and political choices (THORP PAREDES 2011:23-25). Many people, who speak the native language at home, follow the original customs, celebrate the important festivities and wear the traditional clothes would still present themselves as mestizos or campesinos, since the public connection with the native culture often has a negative impact. Nevertheless, even those who identify themselves as mestizos would not automatically avoid racism, as the perception of others may differ. Discrimination of a specific native group tends to deepen cultural and psychological barriers. By comparison, all the Latin American states with a high proportion of indigenous people, such as Mexico, Guatemala, Ecuador, Bolivia and Peru are forced to apply preventive programs against violence (THORP - PAREDES 2011:26-27). Despite the endeavour of

2 VRAEM is an acronym for Valle de los Ríos Apurímac, Ene y Mantaro (Valley of the Rivers Apurímac, Ene and Mantaro) located at the boundary between Ayacucho, Cusco and Junín regions. This area is also known for its poverty and trug trafficking problems.

3 Like for example in some states of the USA, where the native person should have at least one sixteenth of the indigenous blood.

DOI: 10.2478/eas-2018-0010 @ University of SS. Cyril and Methodius in Trnava. All rights reserved. 
many institutions, organisations or official authorities, racism and discrimination still remain serious issues in Peru.

In the past indigenous people had to overcome colonial racism based on religious beliefs, following "scientific racism" formed on the theory by Joseph Arthur de Gobineau who wrote An Essay on the Inequality of Human Races or racism referring to the analphabetism. Sadly, the contemporary racism is even more elaborated. On one hand, indigenous people are discriminated against due to their culture, language, dressing or governing style because that excludes them from the mainstream society ${ }^{4}$. On the other hand, they are disadvantaged owing to the lack of education, health care, good nutrition, hygiene or housing (SIEDER 2002:227-239). The aforementioned Peruvian geomorphology supports the discrimination as well, creating two different areas of indigenous sierra and the coast of mestizos. (THORP PAREDES 2011:20). What is more, discrimination originates not only from "the others" but also from the indigenous people themselves who often label themselves as "ignorant and poor". Mutual confidence is also missing.

The last mentioned phenomenon was confirmed several times during a field research in Peru. The self-confidence and confidence in others are missing from the majority of communities. The illustrative example might be the lack of native people representing their communities at local government or municipalities. People within the Amazon communities San Francisco, Santa Clara and Nuevo Egipto belong to the Yarinacocha district, but they claim too many mestizos and white people live in the area, which means there is no chance to gain a mandate at the municipality. Similarly, other answers were that they would not support the native candidate unless they knew him personally. Within the sierran communities, the replies were alike (OCHAVANO CUNAPA 2014, SOTO CRISPIN 2014). The authors Thorp and Paredes presented the survey focused just on the hypothetical support of an indigenous candidate to the national congress with a negative response from $43 \%$ of mestizos and white people and $29 \%$ of indigenous people. The research also confirmed the assumed fact that higher education influenced positively the way of thinking about native people. (THORP - PAREDES 2011:44).

Accordingly, this slightly far-fetched survey revealed that a significant number of inhabitants believe that the indigenous are violent people. Thorp and Paredes published that $62 \%$ of mestizos and white people agreed with the statement, and what is more, $40 \%$ of natives also

For example, children of native parents are often handicapped at school due to language barrier, unfavourable economic situation or different cultural values. 
claim that indigenous people are violent (THORP - PAREDES 2011:45). Something of that sort was happening in the majority of the municipalities during the research, including the assurance that it is safe to visit original communities since they are not as savage as before (LÁZARO TORALVA 2014). From these results, it is clear that the situation improves more slowly than expected and a prejudice is often mistaken for a fact. The most effective programs implemented by the state and local governments focus on raising public awareness and education, as well as on the involvement of native people, mainly the vulnerable component of indigenous women, into public social life. It follows that many people feel safer and sometimes more confident as mestizos or campesinos rather than face various forms of discrimination.

Indigenous elites and elected officials also make an effort to reverse the stereotypes. However, according to Lomné the perception of a native person with a function is always different. As the anthropologist Eriksen quoted: "Wealth makes people lighter" (ERIKSEN 2012:27). It means, when some indigenous person accepts a public function, the process of mestizaje begins and the perception changes (LOMNÉ 2014:82-89), which is unfortunately also a product of racism and thinking that native people should not hold public posts. Several people intended to turn those ideas, most recently three indigenous women who were elected to the national congress for the term 2006-2011: Juana Huancahuari, Maria Sumire a Hilaria Supa. They became famous for wearing traditional clothes and speaking Quechua during the congress sessions. Their mandate was successful and resulted in the new Ley de Lenguas Indigenas (Law of the Indigenous Languages) that designates 47 indigenous languages as official ones (CULTURAL SURVIVAL 2017). What is more, another two indigenous congressmen from sierra and one from selva were elected for the following term (VILLANUEVA MONTALVO 2012:59).

The last of the aforementioned stereotypes that keep repeating is a resilient connection between indigenous and rural or indigenous and poor (CHIRAPAQ 2017:8), which hardens the position of those indigenous who decide to live in a city. According to the author Henri Favre there is no solution to this situation, as "the indigenous becomes the citizen and stops existing". It is nearly impossible to move into a city and not to lose ethnic identity, use the native language and continue with the traditions. (FAVRE 2007:26). Others perceive this process as mestizaje when people lose their natural environment and ethnic purity, though they gain better social status and modernisation (CUELTO - LERNER 2011:17-24). In contrast to those ideas, there are many native people actually living in the cities without the necessity of leaving their culture or losing the language. There are positive examples in Mexico, Guatemala, Ecuador or Bolivia. In Peru itself, Ayacucho, Puno, Pucallpa or Tingo María could be named as well. The well-known proponent of the modernisation without 
losing the native culture is Juan Ossio Acuña who claims that Quechuas and Aymaras can achieve the incorporation to the modern society without giving up their customs, language, traditional institutions or the cosmovision. In other words, they can maintain the wholeness of their culture (OSSIO ACUÑA 1994:16-17).

As this part shows, education and public awareness hold a key to the way out of the vicious circle of discrimination and unfavourable status of native people. The positive progress continues and some of the results will be mentioned in the last part of this text. Various indigenous organizations deserve the credit for their programmes against racism, even though they realise it is still a long-term process. As the Centre for Indigenous Cultures of Peru CHIRAPAQ ${ }^{5}$ quoted on their website: "To eliminate the racism means deep social and economic changes which cannot be realised yet" (CHIRAPAQ 2015).

\section{Weakening Rivalry}

The previous part dealt with factors, explaining the inclination to the auto-identification with a social class rather than the indigenous ethnicity, like racism, discrimination of native people, or homogenous politics in the second half of the $20^{\text {th }}$ century. On the other hand, there are also some profits connected with the ethnic identity associated with government social programmes, electoral quotas or NGO's projects. The identification with an ethnic group just to benefit from it was described as the instrumental identity or secondary identity. The identification then turns as a product of rational thinking and (often material) goal achievement (PRŮCHA 2010:121). Sometimes it is difficult to distinguish the motives for the particular ethnic identification, mainly among the communities living close to the towns and cities, where the differences between indigenous and mestizo become more blurred. The second external factor influencing the ethnic identification is based on the sense of an external threat. Individuals tend to identify more easily and tightly with their ethnic group when there is a need for collective action or when they face a serious problem. (THORP - PAREDES 2011:20). This indicates that some of the native communities depend on external motivation to take some action. In case of Peru, this works on the level of districts or regions where the communities fight against mining, oil production, deforestation, uneven economy or

5 The Peruvian organisation CHIRAPAQ (Centro de Culturas Indígenas del Perú) was founded more than 30 years ago. Among the main aims belong promoting of indigenos self-awareness, supporting their identity and acknowledgement of indigenous rights. 
discrimination. Nevertheless, there is no such appeal that would unite all the indigenous people nationwide.

Up to now, the dividing factors have been stronger than the uniting ones and the existing rivalry tends to weaken the position of indigenous people in general. The cleavages could be divided into the geographical, political, community, social and religious spheres. The geographical one is patterned on the given ethnic, biotope and legal differences between the regions of sierra and selva. Amazonian native people seem to have a slightly better initial position thanks to the responsive laws and greater autonomy (for example, the autonomous territory of the Wampis nation was recognised in the Loreto region in 2015.) (SERVINDI 2015). The majority of the municipalities include a department for indigenous issues, frequently run by native officials commuting from the communities ${ }^{6}$. Also, the funding is sufficient to support several pro-indigenous projects, more gladly those initiated by the communities themselves. The role of the shielding organization in the selva region was adopted by the Interethnic Association for the Development of the Peruvian Rainforrest $\mathrm{AIDESEP}^{7}$, which is the largest organization helping to protect the rights of native communities and provide them with the greatest autonomy possible. The supporting $\mathrm{CAAAP}^{8}$ organization not only protects the indigenous rights but also helps to research the field and public reference books. Local communities claim to have nothing in common with indigenous people in sierra and vice versa.

Original people of the sierra began their different history even before the conquest when they were united under the Incan Empire. The aforementioned laws at the end of the 1960s completed the process and shifted their status to the agrarian communities instead of the indigenous ones, and until today many scholars have claimed that those original communities do not even exist (HUAMANí 2014). Among many communities labeled comunidades

6 A living example could be the municipality in Pucallpa with the Oficina Municipal de Asuntos Indígenas OMAI (Municipal Office od Indigenous Matters), administrating seven districts with Awajun, Ashaninka and Shipibo ethnicities and providing consultations, protecting the natural environment, promoting education and advocating human rights. Another model functions in San Francisco VRAEM with the Ashaninka communities.

$7 \quad$ AIDESEP (in Spanish Asociación Interétnica de Desarrollo de la Selva Peruana) was founded in 1979 by indigenous representatives with the aim to represent native communities, support farmers and provide necessary support against the oil companies. The leadership is chaired by the National Assembly elected for three years.

8 The Amazonian Centre of Anthropology and Practical Application CAAAP (Centro Amazónico de Anropología y Aplicación Práctica) has existed since 1974. It facilitates intercultural negotiations, promotes indigenous rights and publishes various academic papers dealing with the selva region. 
campesinas by the state are very few who see themselves as comunidades indigenas or more as proud nations. For example, in the Huancavelica region, there are four large communities who (unlike the hundreds of others) identify themselves as indigenous - Chopcca, Anccara, Carcapata and Llillinta. The Chopcca nation tries to obtain an autonomous status and up to now, they are allowed to apply customary law and continue their tradition (ESCOBAR DE LA CRUZ 2014). Although more similar communities could be found within the sierra, especially in the regions of Ayacucho (Quispicanchi), Cusco (Q'eros) and Puno (Uros), they remain underestimated or even invisible. As far as the financing is concerned, the situation is significantly worse and the municipalities struggle with the redistribution of the funding. All the sierran indigenous communities lie within the authority of social departments. Similarly, in 1999 the National Federation of Peruvian Communities Affected by Mining CONACAMI $^{9}$ (Confederación Nacional de Comunidades del Perú Afectadas por la Minería) became the uniting organization, which dealt mainly with communities affected by mining amd omitted the others (LOMNÉ 2014:13).

On this basis, it can be concluded that effective cooperation across the regions is not possible yet. However, the lack of effective collaboration limps along among the authorities and communities as well, which come under political cleavage. The indigenous organizations have the role of an intermediary between the state structures and original population. Apart from the aforementioned ones, a great deal of effort is made by the organisations like CHIRAPAQ that promotes public awareness and dedicate itself to the socio-ethnic programmes or National Organisation of Andean and Amazonian Women from Peru ONAMIAP $^{10}$ (Organización Nacional de Mujeres Indígenas Andinas y Amazónicas del Perú) collaborating mainly with indigenous women. The mistrust in traditional political structures and limited possibility of (self-) representation still remains an important issue to solve (VILLANUEVA MONTALVO 2012:47-48). Similarly, the negative opinion can be observed even among the officials. Some of the local governments share the opinion that the communities do not seek the change, they are not progressive, always look for easy solutions with no effort etc. (WEBB 2011:173). This problem stems from the shortage of effective communication channels either in the horizontal or the vertical level recognised by the officials and indigenous elites (VILLANUEVA MONTALVO 2012:67), which was However, today it is widely seen as fossilized and little productive.

10 ONAMIAP cooperates with indigenous women and native communities since 2009. There are five main aims: authonomy, democracy, equality, interculturlity and reciprocity. 
confirmed during the field research. Not only that the communication and information exchange between the communities and municipalities was poor, but also the communication channel between the municipalities and the state does not work well. What is more, some of the communities in the area of Pucallpa region surprisingly refused to cooperate with the AIDESEP or the local municipality and preferred a regular contact with the Municipal Office for Indigenous Affairs in Pucallpa concerning the issues of trust.

In addition, every municipality has a slightly different vision and the officials are rarely reelected, which makes effective cooperation even more difficult. Elected non-indigenous mayors tend to depreciate initiatives of the communities and, on the other hand, indigenous mayors incline to be exclusive or privilege their own community (OCHAVANO CUNAPA 2014). According to Martí i Puig those mayors keep struggling between the idea of fulfilling the promises given mainly to their voters or making the politics which include all the people of the region (MARTÍ I PUIG 2007:326). As one of the consequences of this divergence, there is almost no collaboration among the neighbouring communities, except traditional reparation of the roads and cleaning of the drains adopted from the Incan times. This leads us to the community sphere, where especially in the sierra it is difficult to mobilise the people since the gap between "us" and "them" is too profound. Latent friction exists between the Aymara and Quechua ethnicities and also between those who see themselves as agrarian on one side and indigenous on the other side (ROEDL 2007:135).

An unusual case of rivalry was discovered during the research in the selva region of Tingo María. Two native communities Soibiri and Bena Jema decided to relocate from the region of Pucallpa and started a new life here, one 17 years ago and the other one 5 years later. Although both of them speak the native Shipibo language, use traditional clothing for special occasions and make traditional jewellery and textiles, they have never found the same wavelength and each tries to profit at the expense of the other one. However, this example was exceptional and the tension among communities hardly ever crosses the line of competitiveness. In contrast, inside each community appears to be a large amount of solidarity, all the members help each other and nearly everyone participates in communitarian work. The only problem appears when it comes to the interests of a family, which creates the basic unit of each community. The development projects coming to the area are always designated in a way that supports the whole community, yet when a member is forced to choose between the profit of a community or just the family, the family wins. The other reasons a tension within the community appear to be land disputes or slight cultural, political and religious differences (MARTÍ I PUIG 2007:326). Religion divides people mainly in selva, where traditional faith met imported Catholicism, and what is more, a large number of 
evangelic denominations became successful by using native languages and searching for isolated communities.

To sum up, the perception of the ethnic identity remains in the process of slow modernisation supported by education and promotion of public awareness by indigenous elites and various organisations. Educated members of the indigenous communities (especially women) are confirmed to have a positive influence on the following generations within the community. Many indigenous people lack necessary information about their actual rights, about the possibilities of elections or awareness about the regional, state or international projects. The number of officials and mayors with claimed allegiance to an indigenous community is continuously increasing, and what is more, new organisations seeking for intercultural dialogue (like CHIRAPAQ, ONAMIAP or SERVINDI ${ }^{11}$ ) are arising to replace the fossilised ones. Nowadays communities and indigenous populations are perceived as compact collectives, and their ethnicity became politicised ${ }^{12}$. It became more important to enter the public sphere and change the private identity into the public one. Intercommunity dialogue depends on the future will to solve the problems together and promote the importance of ethnic rights across the various communities and different regions.

\section{The New Discourse}

The matter of indigenous people has been keeping Peruvian governments occupied since the very beginning of the state, yet the real breakthrough came with the above mentioned multicultural-state constitution from 1993 and the ratification of the 169 ILO Convention a year later. Although this constitution originated from an authoritarian government, it was never changed, only mild adjustments took place in 2002 when the state was decentralised and each region gained a regional government. In the same year, the law about electoral quotas for women, young and native people, was carried through. The last attempts to change the constitution in order to broaden indigenous rights took place in 2003 when the indigenous

11 Intercultural Communication for the More Humane and Diverse World SERVINDI (Comunicación Intercultural para un Mundo Más Humano y Diverso) is dedicated to the effective communication among indigenous communities and authorities and spreading the reliable information.

12 Espinosa, O. - Pajuelo Teves, R. 06/05/2014. La Participacion y Representacion Politica de Pueblos Indígenas. In: Participación y Competencia Politica en el Peru: DESAFIOS DE LA REPRESENTACION POLITICA. Lima: Auditorio del IEP. Available on: http://www.youtube.com/watch?v=ov4Zo3qMo0M. 
council with more than 200 members representing the original communities was formed. However, the modifications were declined by 77 votes (COPPIP 2004:1-2). In the course of time, the promotion of the original culture to the key component of Peruvian society became one of the important goals of the state (ZAPATA - ROJAS 2013:80).

The present course of the Peruvian politics supports an idea of multicultural state and a greater autonomy of the communities. That was the reason for the establishment of the Ministry of Culture in 2010 together with the Vice-ministry of Interculturality (Viceministerio de Interculturalidad), which communicates with local governments, enforces the indigenous rights and coordinates various activities connected with the original lifestyle. The cornerstone of the active indigenous participation in the national politics was laid with the Ley de la Consulta Previa No. 29785 in 2011. Prior Consultation enables the original communities to co-decide about the national programmes and plans that involve their lands ${ }^{13}$ (GOBIERNO PERUANO 2011). Among the 42 consultation processes, which have been realised since 2011, the main topics were mining, contracts with PeruPetro or use of hydrocarbons (CAAAP 2017:7). In some cases, the indigenous territories are not respected since the communities failed to be recognised or the local people denied any ethnic affiliation. Another issue is connected with bribery ${ }^{14}$ (DAVILA PUÑO 2005:108). Following important step proceeded also in 2011 when the ministry published the Ley de Lenguas Indigenas No. 29735, inspired by indigenous congresswomen. Besides Spanish and Quechua, another 47 native tongues gained the status of the official language in the districts where the particular language is spoken, in order to maintain the diverse language heritage via bilingual education and literacy (GOBIERNO PERUANO 2011). In general, the government is using the active politics to awake the ethnic pride again and meet the expectations of a truly intercultural and multiethnic state.

Those laws enable to apply the promised autonomy of the communities in practice. According to Davila Puño, there should be five inviolable spheres, such as the right for the autonomous economy (ownership of the lands, projects), independent politics (independent tools), sovereign jurisdiction (customary law), freedom of religion and autonomous education (in native language) (DAVILA PUÑO 2005:16). According to the constitution,

13 The whole process consists in seven steps: 1. specification of the object, 2. identification of the communities involved, 3. presentation of the project, 4 . information about the project, 5 . evaluation by the indigenous community, 6. dialogue and discussion, 7. final decision.

14 For example, some of the communities in selva agreed with oil extraction in exchange of financial support from the company. 
communities have the right for so-called Peasant Patrols (rondas campesinas) to apply a customary law. Those arguments were supported also by Donna Van Cott who stressed that the communities in the Andes have all the legitimate sources for the self-government. The lack of interest from the national government in the past turned into a self-sustainability of the local populations (VAN COTT 2008:14-21). In other words, every original community should be an indisputable owner of the lands within its borders, apply the most suitable form of organisation, have the right to co-decide about the planned projects or have the right to speak and learn in their own language (ROBLES MENDOZA 2002:201-205). It is believed that the Andean culture is strong enough to deal with all challenges, yet the excessive autonomy could cause social isolation. The authors Pinxten, Verstraete and Longman suggest the continuity of the traditional life with an adaptation of some useful elements from other cultures, in this case the dominant Spanish culture (PINXTEN - VERSTRAETE LONGMAN 2004:95-97).

The greatest achievement is connected with the Wampis nation from the Loreto region in Amazonia, which declared the autonomy on 30th November 2015. The autonomous territory comprises of 85 communities, roughly 15,300 inhabitants in total, represented by 96 independent Irunin (congressmen). Mr. Wrays Pérez Ramírez was elected to the function of the first Pamuk (president) and his primary goal is to protect natural environment of the Amazonia by excluding all the oil companies that entered without a consultation (SERVINDI 2015), promote the unity among the communities and set the rules for the cooperation with indigenous organisations. The national government is not permitted to intervene in internal conflicts and also all the institutions are fully independent. The whole process was enabled by the 169 ILO Convention (AIDESEP 2017).

Furthermore, among the traditional indigenous communities emerged another manner of ethnic presentation or (self-) identification with roots in telurism (telurismo). This trend originated in the Andes and it is based on the respect to the natural forces, especially Mother Earth (Pachamama) and Father Sun (Taita Inti) (FAVRE 2007:65). A special emphasis is placed on the relationship with nature and with the elements. Namely, in the case of Peru, the gradual expansion of Incaism (incaismo) could be observed since the half of the 20th century. The main aim is to restore the value of the traditional culture. Since 1944 Peruvians have been celebrating the ceremony of Inti Raymi ${ }^{15}$ (Sun Ceremony) again, and in the 1960s the

15 Inti Raymi held during the winter solstice on the southern hemisphere (June) was one of the most important ceremonies celebrated within the Incan Empire. It also meant the New Year and new

DOI: 10.2478/eas-2018-0010 C University of SS. Cyril and Methodius in Trnava. All rights reserved. 
rainbow flag became one of the symbols of new Tawantinsuyu ${ }^{16}$ (Incan Empire). On one hand, this movement tends to highly idealise life under the rule of Incas. On the other hand, it contributes to the awakening of ethnic pride (FERNÁNDEZ - ASENSIO 2014:255-257). Moreover, the people living in the towns or cities, who have already lost their native language and customs, seem to identify themselves with this particular thinking more easily.

The Familia Ancestral Kunturkanki ${ }^{17}$ (Ancestral Family Condor Virtue) existing in Lima, Cusco and Ayacucho makes an illustrative model of the aforementioned phenomenon. This organisation gathers the people who consider themselves to be descendants of the indigenous culture but have already lost the contact with the language and traditional everyday customs. Still, they identify themselves as indigenous people. Their mission is to restore the ancestral roots and renew the ethnic identity. In order to continue the Incan tradition, the elites of the group use names in Quechua. For instance, the leader is called Atoq (Fox) and the deputy leader in Ayacucho is known as Puma (Puma). What is more, all the members consider themselves brothers and sisters. The culture of this group is based mainly on the traditional ceremonies worshipping the nature, like spiritual walks to the mountains, ceremonies of the new moon as well as the full moon, equinoxes, winter solstice and the most important summer solstice Inti Raymi that takes place at the ruins of Wari near Ayacucho. Incan symbols, such as the Andean cross Chakana, the flag Wiphala or rainbow flags are essential at every festivity celebrated according to the Quechua culture ${ }^{18}$. Besides promoting the

beginning. The modern celebration continues with traditional dances, purifying ritual and adoration of the Sun and Earth, just the traditional animal sacrifices were replaced by sharing the food.

16 Tawantinsuyu means "the realm of four regions" which consisted of Antisuyu (east), Contisuyu (west), Chinchaysuyu (north) and Collasuyu (south). The Incan conquest began in the Cusco region in 1438 and whole Tawantinsuyu was consolidated in the 1470s. The realm was connected by the system of roads called Qhapaq Nan and Quechua was used as universal language. Most of the inhabitants were working on their fields, breeding animals or serving the nobility, which represented the priviledged class of the society. On the top ruled the sacred Sapa Inca, who was considered god, and his royal family. The hierarchical society obeyed three simple laws: Ama Sua, Ama Llulla and Ama Quella, which means do not steal, do not lie and do not be lazy.

17 Members of Familia Ancestral Kunturkanki try to renew the Incan roots and promote the identification with pre-colombian life style. They share the ideas of reciprocity, great respect to the Sun, Mother Earth and four elements, use traditional symbols, as well as they educate themselves about history, myths and cosmovision. Most of the members live in Lima, nevertheless there are local branches in Ayacucho and Cusco.

18 Everyone participates actively in the ceremonies, preparing wood for fire and food, taking part in the purifying act with flower water (agua florida) and smoke, obtaining ceremonial ribbon and quintu of coca leaves, worshipping the Mother Nature (Pachamama), Father Sun (Taita Inti) and Absolute Energy (Pachakamak), burning the quintu together with a secret wish and finally sharing the moment and eating together. Information based on the field research in Peru. 
traditional culture the organisation also dedicates to the education and protection of the natural environment.

Even though the official politics of the Peruvian state continues focusing on liberal economy and supporting the supranational companies, this part proves that the indigenous organisations, leaders of the communities and the dedicated ministries (mainly the Ministry of Culture, the Ministry of Education or the Ministry of Social Development) have a great impact on the improvement of the position of native communities. The current status of the Peruvian indigenous people will become more transparent after the publication of the 2017 census results. However, all leaders of the indigenous organisations and authorities within the original communities are instrumental in building a strong cultural identity and seeking a way of coordinating and representing indigenous people in the largest area possible, which still remains difficult due to deep differences among the communities nationwide or the reluctance to make compromises. To create a successful movement requires the uniting issues, claims and goals (LOMNÉ 2014:30-35). For now, the most important is the positive shift in thinking. Juan Ossio Acuna believes in the possibility of state modernization without losing the traditional ethnics. The other way around, the original means the modern (OSSIO ACUÑA 1994:16-17).

\section{National Census 2017 and the Future of Indigenous Communities}

The highly anticipated 2017 national census results should bring more light to the future of the indigenous communities in Peru. Since the beginning of the $21^{\text {st }}$ century indigenous organisations, mainly the CHIRAPAQ intended to include the right for ethnic autoidentification into the national census. The pilot attempt to map ethnicity based on the autoidentification took place in 2001 during the national inquiry of the households. Officially, the 2017 census included the question about the ethnic (self-) identification. For the first time, there will be an almost exact number of people who consider themselves as indigenous without an external label or determination. The preceding campaign Raices que Cuentan (Roots that Count) organized by the ONAMIAP was meant to increase the awareness about the opportunity to demonstrate the ethnicity, personalise the issue and support ethnic pride. The ONAMIAP visited most of the regions with the main motto Soy indigena, soy del Perí ${ }^{19}$. 
Another goal of the organisation was to promote and emphasise the existence of indigenous communities to the national government (ONAMIAP 2017).

The census had to cover 1867 districts and more than 7000 communities during September (in Lima) and October 2017. The Statistic Institute explained the placement of a new question with the necessity to establish a more appropriate politics towards the indigenous communities based on the real data. As a result, the state could also reassess the actual perception of the indigenous and afroperuvian people and apply more sensitive programs to the particular geographic areas, as the ethnic identity plays an important role in three areas political, cultural and social. Also, the intercultural dialogue would become more objective. The rights for the auto-identification have all the inhabitants older than 12 years of age (INEI 2017). The phrasing of the ethnic question within the 2017 census was: Concerning your customs and ancestors, do you feel like or do you consider yourself as...? And there were the following answers:

\section{Quechua}

\section{Aymara}

Nativo o Indigena de la Amazonía (with specification)

Belonging to other Indigenous or Original pueblo (with specification)

Black, Zambo, Mulatto, Brown or Afroperuvian pueblo

White

Mestizo

Other (with specification)

An interesting fact is that there is no possibility such as campesino or agrarian which means that native communities living in the sierra were supposed to decide either for Quechua, Aymara, Mestizo or Other. It is widely known that despite the ethnic awareness, it also depends on the form of the question. Some of the Peruvian inhabitants surely looked for the answer considering their habits and culture of their antecedents ${ }^{20}$ (ONAMIAP 2017).

What does it mean to be an indigenous person in Peru? The census triggered a fresh wave of discussions concerning ethnicity, and the auto-identification turned into a decisive factor in the context of recognition of indigenous rights. Apart from the identification, an elimination of the prejudices mentioned in the previous parts also became a priority. Within an informative campaign about the 2017 census, the CHIRAPAQ organization surveyed a common characteristic of the indigenous people from sierra and selva in order to encourage 
the sense of belonging. Respondents suggested traditional clothes, customs, shared history and origin as something they have in common. Accordingly, some of the joint problems were identified as well, like discrimination, lack of opportunities, poverty, analphabetism or malnutrition (CHIRAPAQ 2017:5, 8, 36). From those answers, it is clear that the bond among communities across the regions remains weak. However, the multiethnicity of the state has shifted from theory in the 1990 s to the reality in the 2010s when identification with the indigenous origin seems easier than ever before.

\section{Conclusion}

In conclusion, it appears that the process of ethnic auto-identification in Peru is far from a simple assignment. On the contrary, the whole complex of factors like awareness, confidence, education, geography, laws, pride, politics, social and economic status or religion are involved. The constitution authorised in 1993 and ratification of the 169 ILO Convention merely started the process of positive changes in the perception of the ethnicity. The real transformation happened with the decentralisation, Ley de la Consulta Previa and Ley de Lenguas Indigenas that enabled indigenous people to actively participate in the public life. The ethnic identity exceeded the private sphere and actively forms the role of an individual within the society. Although the ethnic variety in Peru is very diverse, a considerable number of native people preferred to identify themselves with a non-indigenous identity until recently. Some of the most discouraging factors for an ethnic affiliation were aforementioned racism and related discrimination, when the words indio, nativo or indigena gained the connection with various prejudices and stigmas. Unfortunately, similar perceptions exist among the indigenous people as well since they often call themselves ignorant and poor,

20 According to the example found within the statistics of the Centro de Culturas Indígenas del Perú CHIRAPAQ (Centre of Indigenous Cultures in Peru) and Marcos Valdés, illustrative example happened in the case of Chile. The Chilean census question for the year 1992 was: As a citizen of Chile, do you consider yourself as a member of some the following cultures? In 2002 the question slightly changed to: Do you belong to some of the indigenous or original pueblos? This shift resulted in statistic decrease of members belonging to some of the native cultures, even though the real state remained unchanged (MAPUNET 2004). 
which results in debilitating distrust. Dealing with those problems has gradually become one of the priorities of indigenous organisations.

Pro-indigenous associations and indigenous elites have a function of an intermediate between the state and communities. However, their impact still remains only regional or local and there is no nationwide organisation defending the native peoples' rights. Recently, the groups like CHIRAPAQ or ONAMIAP have transformed and now they are trying to include as many indigenous cultures as possible to revalue their ethnic origin. Their influence is noted within many communities that reassessed passive acceptation of a status quo and started to fight for the fair status. Yet, the (self-)confidence of the native people themselves makes only a little difference since there is a need for a society-wide change in the perception of original communities. The best solution with regard to a status of indigenous people within a modern state was outlined by Juan Ossio Acuña with his theory of modernisation without losing the original culture. Some of the cited authors claim that for a strong bond there is a need either for a serious threat or some resulting advantages, which are still missing in Peru. One of the key elements is to find the common platform and cooperate together. When the status of indigenous people, in general, is high, every community included could profit from it, which would make the ethnic auto-identification even more sensible.

In contrast, various researchers showed that the communities still tend to seek for differences rather than similarities. For example, a distinct religious belief could be the reason for excluding people from the community or for a complete change of ethnic affiliation. In addition, the aforementioned social, political or economic differences have also a huge impact on an ethnic perception, as pro-indigenous municipalities tend to encourage the ethnic auto-identification and vice versa. As a result of geographical distinction, it could be anticipated that people living in the selva region, especially those who experienced the forthcoming policy of the authorities, are more likely to auto-identify with a native ethnicity in comparison to the sierra region. Those differences were intensified with the Ley de la Reforma Agraria and continued with uneven funding or under-representation in the sierra. The illustrating case of the autonomous Wampis nation was described as one of the most successful steps in order to restore indigenous rights. On the other hand, the sierran nations like Chopcca are still kept in reference as agrarian communities and their power is limited. Nevertheless, the category campesino was missing at the 2017 census, so the results will indicate the current perception of the sierran identity. Either it could finally help to change the constitution together with the outer perception or it would show that sierran indigenous people have chosen an alternative way. 
PAVLÍNA SPRINGEROVÁ - ZDEŇKA PICKOVÁ

Aspects Determining the Auto-identification of Native Communities in Contemporary Peru

The 2017 census, in general, was meant to increase the ethnic pride and public awareness about the indigenous question. Although the campaign Raices que Cuentan and the responsive laws proceeded within the last decade are expected to have a positive impact on the ethnic consciousness, the past experience, lack of information or distrust still tend to shift the perception reversely.

\section{Acknowledgements}

The article is an outcome of the specific academic research Indigenous Movements in Peru supported by the Student Grant Competition of the Philosophical Faculty, University of Hradec Králové.

\section{Bibliography}

AIDESEP Asociación Interétnica de Desarrollo de la Selva Peruana: Misión, 2017 [online]. AIDESEP. [cit. 12/12/2017]. Available on: <http://www.aidesep.org.pe>.

ALBÓ, Xavier (2002): Pueblos Indios en la Política. La Paz: CIBCA.

APARICIO, Pedro Mayor - BODMER, Richard (2009): Pueblos Indígenas de la Amazonía Peruana. Iquitos: Fundamazonía.

ARAGÓN, Jorge Trelles (2012): Participacipación y Representación Política Indígena. Perfil Electoral y Orientaciones Políticas de la Población Indígena del Perú. Lima: Jurado Nacional de Elecciones.

ASSIES, Willem (2009): Los Retos de América Latina en un Mundo en Cambio. Pueblos Indígenas y Sus Demandas en los Sistemas Políticos. In Revista CIDOB d'Afers Internacionals, No. 85-86, pp. 89-107.

BARŠA, Pavel (2006): Konstruktivismus a politika identity. In AntropoWEBZIN, Vol. 2006, No. 1-2, pp. 21-35.

BDPI Base de Datos de Pueblos Indígenas e Originarios: Mapa de Pueblos Indígenas $u$ Originarios, 2018 [online]. BDPI [cit. 15/02/2018]. Available on: <http://bdpi.cultura.gob.pe/node/105\#main-content>.

CAAAP Centro Amazónico de Antropología y Aplicación Práctica. (2017): ¿Cómo va la Aplicación de la Consulta Previa en el Perú?: Avances y Retos 2017. Lima: CAAAP. 
CAAAP Centro Amazónico de Antropología y Aplicación Práctica: El Congreso no Puede Seguir Aprobando Leyes que Afectan a la Amazonía sin Consultar a los Pueblos Indígenas, 2017 [online]. Vega Días, Ismael [cit. 20/02/2018]. Available on: <http://www.caaap.org.pe/website/2017/06/27/el-congreso-no-puede-seguiraprobando-leyes-que-afectan-a-la-amazonia-sin-consultar-a-los-pueblos-indigenas/> .

CÁNEPA, Gisela (2008): The Fluidity of Ethnic Identities in Peru. In CRISE: Centre for Research on Inequality, Human Security and Ethnicity, July 2008, Vol. 48, pp. 1-50.

COPPIP. Coordinadora Permanente de los Pueblos Indígenas del Perú. (2004): Derechos de los Pueblos Indígenas y Comunidades en la Constitución Política del Perú. Lima: COPPIP.

CUELTO, Marcos - LERNER, Adrián (2011): Desarrollo, Desigualdades y Conflictos Sociales. Una Perspectiva Desde los Países Andinos. Lima: Instituto de Estudios Peruanos.

DAVILA PUÑO, Julio (2005): Gobiernos Locales y Pueblos Indígenas. Lima: Grupo de Trabajo Racimos de Ungurahui.

CHIRAPAQ (2017): ¿Es Útil Ser Indígena? Identidad, Censos y Políticas Públicas. Lima: CHIRAPAQ.

CHIRAPAQ Centro de Culturas Indígenas del Peru: ¿Que Puede Hacer el Perú para Enfrentar el Racismo?, 2015 [online]. Culturas y Derechos Indígenas [cit. 24/02/2018]. Available on: <http://chirapaq.org.pe/es/que-puede-hacer-el-peru-para-enfrentar-elracismo>.

CULTURAL SURVIVAL: Peru Oficially Recognizes Indigenous Languages, 2017 [online]. Cultural Survival. [cit. 30/12/2017]. Available on: $<$ https://www.culturalsurvival.org/news/peru-officially-recognizes-indigenouslanguages $>$.

ERIKSEN, Thomas Hylland (2012): Etnicita a nacionalismus. Antropologické perspektivy. Praha: SLON.

ESCOBAR DE LA CRUZ, Pablo (01/05/2014): Regidor de la Comunidad Ccasapata Chopca, Huancavelica. Interview.

ESPINOSA, Oscar - PAJUELO TEVES, Ramón (2014): La Participación y Representación Política de Pueblos Indígenas. In: Participación y Competencia Política en el Peru: DESAFIOS DE LA REPRESENTACION POLITICA. Lima: Auditorio del IEP. Available on: <http://www.youtube.com/watch?v=ov4Zo3qMo0M>

FAVRE, Henri (2007): El Movimiento Indigenista en América Latina. Lima: Instituto Francés de Estudios Andinos. 
FERNÁNDEZ, Ignacia M. - ASENSIO, Raúl H. (2014): ¿Unidos Podemos? Coaliciones Territoriales y Desarrollo Rural en América Latina. Lima: Instituto de Estudios Peruanos. GOBIERNO PERUANO (1993): Peruvian Constitution 1993. Constitución Política del Peru de 1993. Available on: <http://www.pcm.gob.pe/wpcontent/uploads/2013/09/Constitucion-Pol\%C3\%ADtica-del-Peru-1993.pdf>.

GOBIERNO PERUANO (2011): Ley No. 29785, Ley del Derecho a la Consulta Previa a los Pueblos Indígenas u Originarios, Reconocido en el Convenio 169 de La Organización del trabajo. "Law of the Prior Consultation". 2011. Available on: <http://consultaprevia.cultura.gob.pe/wp-content/uploads/2014/11/Ley-N---29785-Leydel-derecho-a-la-consulta-previa-a-los-pueblos-ind--genas-originarios-reconocido-enel-Convenio-169-de-la-Organizacion-Internacional-del-Trabajo-OIT.pdf>.

GOBIERNO PERUANO (2011): Ley No. 29735, Ley de Lenguas Indígenas que regula el uso, preservación, desarrollo, recuperación, fomento y difusión de las lenguas originarias del Perú. "Law of the Indigenous Languages". Available on: <http://red.pucp.edu.pe/ridei/files/2011/08/LEY-NACIONAL-DE-LENGUAS.pdf>.

HENRÍQUEZ RAMÍREZ, Alfonso (2013): Participación Indígena Desarrollo y Alcances en Torno a la Participación Ambiental. In Revista lus et Praxis, Vol. 19, No. 2, pp. 251 300.

HUAMANÍ, Pedro (2014): Sub-gerencia de Planificacion del Gobierno Regional de Ayacucho. Interview.

IEP Instituto de Estudios Peruanos: Organización, 2017 [online]. IEP. [cit. 15/02/2018]. Available on: <https://iep.org.pe/quienes-somos/organizacion/>.

ILO International Labour Organisation (1980): Indigenous and Tribal Population Convention 169. Available on: <http://www.ilo.org/wcmsp5/groups/public/---americas/--ro-lima/documents/publication/wcms_345065.pdf $>$.

INEI Instituto Nacional de Estadística e Informatica: ¿Qué es la Indentificación Étnica y Cuál es su Importáncia?, 2017 [online]. INEI. [cit. 30/01/2018]. Available on: <http://www.censos2017.pe/autoidentificacion/>.

KLÍMA, Jan (2015): Dějiny Latinské Ameriky. Vývoj oblasti, regionů a států. Praha: NLN.

LÁZARO TORALVA, Samuel (2014): Unidad de Comunidades Campesinas y Participacion Ciudadana del Gobierno Regional de Huancavelica. Interview.

LOMNÉ, Georges (2014): De la Política Indígena. Perú y Bolivia. Lima: Instituto de Estudios Peruanos.

MADRID, Raúl L. (2005): Indigenous Parties and Democracy in Latin America. In Latin American Politics and Society, Winter 2005, Vol. 47, No. 4, pp. 161-179.

DOI: 10.2478/eas-2018-0010 @ University of SS. Cyril and Methodius in Trnava. All rights reserved. 
PAVLÍNA SPRINGEROVÁ - ZDEŇKA PICKOVÁ

Aspects Determining the Auto-identification of Native Communities in Contemporary Peru

MADRID, Raúl L. (2011): Ethnic Proximity and Ethnic Voting in Peru. In Journal of Latin American Studies, Vol.43, Cambridge University Press 2011, pp. 267-297.

MAINWARING, Scott - BEJARANO, Ana María - LEONGÓMEZ, Eduardo Pizarro (2006): The Crisis of Democratic Representation in the Andes. Standford: Standford University Press.

MAPUNET Pueblo y Teritorio Mapuche: Reflexiones Metodológicas en Torno a los Censos 1992-2002, 2004 [online]. Valdés, M. [cit. 15/01/2018]. Available on: <https://www.mapunet.org/documentos/mapuches/Ref_met_cen_1992-2002.pdf>.

MARTí I PUIG, Salvador (2007): Pueblos Indígenas y Política en America Latina. El Reconocimiento de sus Derechos y el Impacto se sus Demandas a Inicios del Siglo XXI. Barcelona: Fundación CIDOB.

MINISTERIO DE CULTURA: Interculturalidad, 2017 [online]. Ministerio de Cultura. [cit. 15/12/2017]. Available on: <http://www.cultura.gob.pe/es/interculturalidad>.

MINISTERIO DE JUSTICIA, Direccion Nacional de Asuntos Jurídicos. (2000): Compendio de Legislación para los Pueblos Indígenas y Comunidades Nativas. Volumen I. 2nd edition. Lima: La Defensoría del Pueblo.

MINISTERIO DE JUSTICIA, Direccion Nacional de Asuntos Jurídicos (2000): Compendio de Legislación para los Pueblos Indígenas y Comunidades Nativas. Volumen II. 2nd edition. Lima: La Defensoría del Pueblo.

NIEZEN, Ronald (2003): The Origins of Indigenism: Human Rights and the Politics of Identity. London. University of California Press.

OCHAVANO CUNAPA, Richard (2014): Jefe de la Comunidad San Francisco, Pucallpa. Interview.

ONAMIAP Organización Nacional de Mujeres Indígenas Andinas y Amazónicas del Perú: Campaña Raíces que Cuentan, 2017 [online 2018]. ONAMIAP. [cit. 01/03/2018]. Available on: <http://onamiap.org/campana-raices-que-cuentan/>.

ONPE Oficina Nacional De Procesos Electorales (2011): Participación de la Población Indígena Amazónica en las Elecciones Regionales y Municipales 2010. Lima: ONPE.

OSSIO ACUÑA, Juan (1994): Las Paradojas del Peru Oficial. Lima: Pontifica Universidad Catolica del Peru.

PAJUELO TEVES, Ramón (2006): Participación Política Indígena en la Sierra Peruana. Una Aproximación desde las Dinámicas Nacionales y Locales. Lima: Instituto de Estudios Peruanos. 
PINXTEN, Rik - VERSTRAETE, Ghislain - LONGMAN, Chia (2004): Culture and Politics. New York: Berghahn Books.

PLENO JuRAdo naCiOnAL DE ElECCIONES. (2010): Perfil del Elector Peruano. Voto Informado. Lima: Jurado Nacional de Elecciones.

PRŮCHA, Jan (2010): Interkulturní psychologie. Sociopsychologické zkoumání kultur, etnik, ras a národů. Third Edition. Praha: Portál.

ROBLES MENDOZA, Román (2002): Legislación Peruana Sobre Comunidades Campesinas. Lima: Fondo Editorial de la Facultad de Ciencias Sociales, Universidad Nacional Mayor de San Marcos.

ROEDL, Bohumír (2007): Dějiny Peru a Bolívie. Praha: Nakladatelství Lidové Noviny.

ROMANCOV, Michael (2012): Postavení původního obyvatelstva jako velké politické téma současnosti. In Mezinárodní politika, Vol. XXXVI, No. 10/2012. pp. 4-6.

SAAVEDRA NAVARRETE, Rodrigo (2010): Gobernabilidad Neoliberal y Movimientos Indígenas en América Latina. In Polis Revues, April 2012, No. 27, pp. 1-14.

SALMÓN, Elizabeth (2011): Entre las Promesas de la Consulta Previa y la Continuidad de la Protesta Social: Las Ambigüedades de la Participación Política Indígena en el Perú. In Cajías de la Vega, Beatriz (ed.): Participación Política Indígena y Políticas Públicas para Pueblos Indígenas en América Latina. La Paz: Participación Política Indígena. Fundación Konrad Adenauer, pp. 279-311.

SERVINDI Comunicación Cultural para un Mundo más Humano y Diverso: Pueblo Wampis conforma primer gobierno autónomo indígena del Perú, 2015 [online]. SERVINDI. [cit. 16/02/2018]. Available on: <https://www.servindi.org/actualidad/144577>.

SIEDER, Rachel (2002): Multiculturalism in Latin America. Indigenous Rights, Diversity and Democracy. London: Institute of Latin American Studies.

SOLO DE ZALDÍVAR, Victor Bretón (2005): Capital Social y Etnodesarrollo en los Andes. La Experiencia PRODEPINE. Quito: Centro Andino de Asociación Popular.

SOTO CRISPIN, Florentino (2014): Gestor Institucional de Tambo Chopca. Interview.

THORP, Rosemary - PAREDES, Maritza (2011): La Etnicidad y la Persistencia de la Desigualdad. Lima: Instituto de Estudios Peruanos.

VAN COTT, Donna Lee (2008): Radical Democracy in the Andes. New York. Cambridge University Press.

VAN COTT, Donna Lee (2005): From Movements to Parties in Latin America. The Evolution of Ethnic Politics. New York: Cambridge University Press. 
PAVLÍNA SPRINGEROVÁ - ZDEŇKA PICKOVÁ

Aspects Determining the Auto-identification of Native Communities in Contemporary Peru

VILLANUEVA MONTALVO, Aída (2012): En Torno a la Representación Especial Indígena en el Perú: Percepción de Líderes Indígenas y Características del Modelo Peruano. In Debates en Sociología, No. 37, pp. 43-76.

WEBB, Adam K. (2011): Nuestro Propio Sendero. Una Comunidad Andina y la Economia de Valores del Maňana. Lima: Instituto de Estudios Peruanos.

ZAPATA, Antonio - ROJAS, Rolando (2013): ¿Desiguales Desde Siempre? Miradas Historicas Sobre la Desigualdad. Lima: Instituto de Estudios Peruanos. 